\title{
Hemin Based Biomimetic Oxidative Degradation of Acid Orange 7
}

\author{
Mei Yan1, Huifang Xie1*', Qing Zhang1, Hongxia Qu², Jinyou Shen"1, Jinming Kong1 \\ ${ }^{1}$ School of Environmental and Biological Engineering, Nanjing University of Science and Technology, Nanjing, \\ China \\ ${ }^{2}$ School of Chemical Engineering, Nanjing University of Science and Technology, Nanjing, China \\ Email: "huifangxie@hotmail.com
}

Received 25 April 2016; accepted 20 May 2016; published 24 May 2016

\begin{abstract}
Degradation of dyes is an important environmental issue. In order to avoid the carcinogenic risks in anaerobic-aerobic biological process for wastewater containing azo dyes, a hemin based biomimetic oxidative degradation of azo dyes was developed. Acid orange 7 (A07) was selected as the model for azo dye and the high efficient degradation was achieved in hemin $/ \mathrm{H}_{2} \mathrm{O}_{2}$ system at $\mathrm{pH}$ 11.0. Degradation could be described by a pseudo-first-order kinetic model. The order of dependence on $\mathrm{H}_{2} \mathrm{O}_{2}$ concentration was significantly larger than that of hemin. Coexisting anions sulphate and chloride had little effect on the degradation, but reductive sulphite dramatically inhibited the degradation. The protic solvent 2-prophanol obviously promoted the degradation. Azo chromogenic group was destroyed quickly and some smaller intermediates formed. Active species oxoferryl porphyrin $\pi$-cation radical ${ }^{+}+\mathrm{PFe}^{\mathrm{IV}}=0$ generated from heterolytic cleavage of $0-0$ in $\mathrm{H}_{2} \mathrm{O}_{2}$ catalyzed by hemin play the main roles in degradation and reaction pathways were proposed.
\end{abstract}

\section{Keywords}

\section{Biomimetic Oxidative Degradation, Azo Dyes, Hemin}

\section{Introduction}

The removal of dyes from water is one of the most important issues for industries such as textile, paper, leather, pharmaceutical, food and so on [1]-[5]. Azo dyes represent 50\% - 70\% of all dyes and 10\% - 15\% are released into wastewater. Most wastewater containing azo dyes is treated in wastewater treatment plants by traditional biological methods based on anaerobic-aerobic process [6]. These processes are relatively ineffective in degradation of dyes and significant parts of azo dyes release carcinogenic aromatic amines by microbial reductive cleavage of $-\mathrm{N}=\mathrm{N}$ - under anaerobic condition and toxicity increases instead [7] [8]. So it is necessary for azo dyes to become smaller and less toxic molecules by destroying the azo chromogenic groups before draining.

Oxidative degradation of azo linkage is approved to be more effective than anaerobic reductive cleavage and some oxidative systems have been reported [6] [9]. However, there are some disadvantages in chemical oxidative

\footnotetext{
${ }^{*}$ Corresponding author.
}

How to cite this paper: Yan, M., Xie, H.F., Zhang, Q., Qu, H.X., Shen, J.Y. and Kong, J.M. (2016) Hemin Based Biomimetic Oxidative Degradation of Acid Orange 7. Journal of Materials Science and Chemical Engineering, 4, 26-34. 
systems [4] [6] [9]-[11], such as narrow and acid pH range, long reaction time, use of non-convenient chemical reagents and generated large amount of sludge. Most wastewater from textile effluents are highly alkaline [12] [13], so it is cost-prohibitive because of large amount of acidic and alkaline chemicals used for pH adjustment.

The effective biological systems for oxidative degradation of azo dyes mainly are peroxidase systems, such as horseradish peroxidase $/ \mathrm{H}_{2} \mathrm{O}_{2}$ [14] [15], manganese peroxidase $/ \mathrm{H}_{2} \mathrm{O}_{2}$ [16] and lignin peroxidase/ $\mathrm{H}_{2} \mathrm{O}_{2}$ [17]. The group ferriprotoporphyrin IX in the active center of the enzymes plays the main catalytic role in peroxidase systems. Hemin is biomimetic compounds of peroxidase and have shown very good efficiency for hydrogen peroxide activation in alkene epoxidations [18] and in degradation of dyes [3] [5] [12] [19]. There were different characteristics and mechanisms reported about the degradation of dyes catalyzed by hemin. So it is necessary to understand the catalytic reaction of hemin on the oxidative degradation of dyes deeply. Therefore acid orange 7 (AO7) was selected as a model for azo dye [3] and efficient oxidation system with low concentration of hydrogen peroxideunder hemin catalysis were investigated in this work. The influential operational parameters on the oxidative degradation of AO7 were explored. Then the reaction kinetics was studied and the kinetic rate coefficients were determined based on the experimental data. Based on the kinetic and characteristic analysis of degradation process, the possible degrading pathway was proposed.

\section{Experimental}

AO7 was dissolved in $0.2 \mathrm{M} \mathrm{Na}_{2} \mathrm{HPO}_{4}-\mathrm{NaH}_{2} \mathrm{PO}_{4}-\mathrm{NaOH}$ buffers for desired $\mathrm{pH}$ stock solutions with $0.67 \mathrm{mM}$. Hemin was dissolved in the N,N-Dimethylformamide with $0.1 \mathrm{mM}$ and diluted 10 times with water before used.

The experiments were conducted by varying the parameters such as $\mathrm{pH}$, hemin concentration, $\mathrm{H}_{2} \mathrm{O}_{2}$ concentration, temperature, co-exiting anions and protic solvent. For degradation experiment, the AO7 stock solution was diluted to the desired concentration with buffer solution with same $\mathrm{pH}$, then corresponding volume of $\mathrm{H}_{2} \mathrm{O}_{2}$ and hemin solution were added in turn and the mixture reacted in a constant temperature bath. The related parameter values were shown in figure captions.

At certain reaction time, absorbance of samples at $484 \mathrm{~nm}$ was recorded with a T6 Uv-vis spectrophotometer (Purkinje Co., China) and the residual concentrations of AO7 was calculated. The buffer solution with same pH was used to dilute immediately if necessary. The degradation ratio was evaluated as $\left(1-\frac{\mathrm{C}}{\mathrm{C}_{0}}\right) \times 100 \%$, and $\mathrm{C}_{0}$ and $\mathrm{C}$ were the initial and the residual concentration of AO7 respectively. Blank was done at the same time in each group experiments, in which the same volume buffer solution was used to take the place of hemin solution.

For FTIR and GC-MS analysis, the reaction mixture was acidified with $0.4 \mathrm{~mL} 1 \mathrm{M} \mathrm{HCl}$ and kept stirring for 5 min with $2 \mathrm{~mL} \mathrm{CH}_{2} \mathrm{Cl}_{2}$ for extraction of reaction products at certain time. Then the extracted solution was dehydrated with anhydrous sodium sulfate and concentrated to $0.5 \mathrm{~mL}$. The FTIR spectra were recorded on a thermo Nicolet iS10 FTIR spectrometer. $10 \mu \mathrm{L}$ concentrated extract was deposited on a pure $\mathrm{KBr}$ thin disk and solvent was removed under the IR lamp. For GC-MS (Agilent 7890A/5975C), a HP-5 MS capillary column (30 m $\times$ $0.25 \mathrm{~mm} \times 0.25 \mu \mathrm{m}$ ) was employed for GC separation. The GC was operated in a temperature programmed mode with an initial temperature of $60^{\circ} \mathrm{C}$ held for $2 \mathrm{~min}$, then ramped to $250^{\circ} \mathrm{C}$ with a $20^{\circ} \mathrm{C} / \mathrm{min}$ rate.

The dissolved oxygen concentration profiles were recorded with a Dissolved Oxygen Meter (Mettler-Toledo SG6-ELK) at $15^{\circ} \mathrm{C}$ with magnetic stirring.

\section{Results and Discussion}

\subsection{Degradation Kinetics Analysis}

$\mathrm{pH}$ is a highly important factor for effective oxidation of AO7 in hemin/ $\mathrm{H}_{2} \mathrm{O}_{2}$ system. Degradation of AO7 achieved in alkaline medium and increasing degradation ratios and rate were observed with increased original pHs in our study. The similar results were reported when hematin, the hydorxylated hemin, was used to catalyze the conversion of orange II at higher peroxide concentrations [3]. Alkaline medium are benefit for reaction of hemin and AO7. De Villiers et al. [20] observed a maximum of the dimerization constant of ferriprotoporphyrin IX in aqueous solution at $\mathrm{pH} 7$, decreasing afterward, so increased $\mathrm{pH}$ may be associated with disaggregation of hemin dimmers, which account for higher availability to substrate attack. On the other hand, AO7 is in favor of equilibrium shift to azo form for AO7 [1]. A pKa corresponding to the $-\mathrm{OH}$ of $\mathrm{AO}$ is 10.7 [21], so $-\mathrm{OH}$ can dissociate to form azo body with phenolate ion at $\mathrm{pH} 11.0$ [22] and phenolate ion is more easily oxidized [23] 
[24]. Negatively charged species of AO7 at higher pH may favor disaggregation while molecular of AO7 aggregates in neutral solution [3] [25]. The result is quite valuable because of highly alkaline of much textile wastewater [12] [13], and the hemin/ $\mathrm{H}_{2} \mathrm{O}_{2}$ system can be used directly without $\mathrm{pH}$ adjusting.

With regard to the actual $\mathrm{pH}$ of dyeing wastewater and characteristics of AO7, the next study was carried out at $\mathrm{pH}$ 11.0. The degradation profile of $\mathrm{AO} 7$ follows an exponential pattern and can be described well according to the pseudo-first-order kinetics reaction model, $\ln \left(\frac{\mathrm{C}}{\mathrm{C}_{0}}\right)=-\mathrm{k}_{\mathrm{obs}} \mathrm{t}$, in which $\mathrm{k}_{\mathrm{obs}}$ represents the reaction rate coefficient and $\mathrm{t}$ represents the time. $\mathrm{k}_{\mathrm{obs}}$ is represented by the Arrhenius equation in linear form:

$$
\ln \mathrm{k}_{\mathrm{obs}}=\ln \mathrm{k}^{\prime}+\left(-\frac{\mathrm{E}_{\mathrm{a}}}{\mathrm{RT}}\right)
$$

where $\mathrm{k}^{\prime}$ is the frequency factor, $\mathrm{E}_{\mathrm{a}}$ the activation energy, $\mathrm{T}$ the temperature and $\mathrm{R}$ the gas constant (8.314 $\mathrm{J} \cdot \mathrm{mol}^{-1} \cdot \mathrm{K}^{-1}$ ). At constant $\mathrm{pH}$, the frequency factor $\mathrm{k}^{\prime}$ in Equation (1) is a function of the hemin and $\mathrm{H}_{2} \mathrm{O}_{2}$ concentration and they can be related by the following equation:

$$
\mathrm{k}^{\prime}=\mathrm{k}^{\prime \prime}[\mathrm{Hemin}]^{\mathrm{p}}\left[\mathrm{H}_{2} \mathrm{O}_{2}\right]^{\mathrm{q}}
$$

in which [Hemin] and $\left[\mathrm{H}_{2} \mathrm{O}_{2}\right]$ are the concentrations of hemin $(\mu \mathrm{M})$ and $\mathrm{H}_{2} \mathrm{O}_{2}(\mathrm{mM})$ respectively,p and q the orders of dependence respectively. The order of dependence on concentrations of hemin and $\mathrm{H}_{2} \mathrm{O}_{2}$ at $\mathrm{pH} 11.0$ is 1.190 and 1.596 respectively (see Figure 1) according to the experiment results.

The order of dependence on $\mathrm{H}_{2} \mathrm{O}_{2}$ is significantly larger than that of hemin and the result is in keeping with the highly sensitive detection for $\mathrm{H}_{2} \mathrm{O}_{2}$ of linked hemin on the PEI-AuNP in our study [26].

The increase of temperature results the increase of degradation rate, especially the initial $5 \mathrm{~min}$. So the initial slope of the observed discoloration was used to calculate the rates at different temperatures and Figure 1(c) gives the Arrhenius plot of $\operatorname{lnk}_{\text {obs }}$ versus $1 / T$ at constant $\mathrm{H}_{2} \mathrm{O}_{2}$ and hemin concentrations. According to the plot, $\mathrm{E}_{\mathrm{a}}$ is about $37.0 \mathrm{~kJ} \cdot \mathrm{mol}^{-1}$, which is lower than the Ea value $\left(43.5 \mathrm{~kJ} \cdot \mathrm{mol}^{-1}\right)$ of $\mathrm{AO}$ oxidized by heterogeneous photo-Fenton system [27]. The $E_{a}$ value suggests ion-molecule or radical-molecule reactions, which requiring activation energy [27] happens during the degradation of AO7.

The last degradation ratios are similar when temperature is above $15^{\circ} \mathrm{C}$ in our study, so temperature was not so important as other factors and the reaction can be carried out at room temperature. From this point, he$\mathrm{min} / \mathrm{H}_{2} \mathrm{O}_{2}$ system is very suitable for pre-treating the actual dyeing wastewater under different temperature.

\subsection{Effects of Coexisting Anion}

Chloride and sulfate sodium salts are frequently used dye-assisting chemicals in the dyeing process [28], and $\mathrm{SO}_{3}^{2-}$ is a kind of reductive anions. Their effects on degradation of AO7 are tested. The results in Figure 2

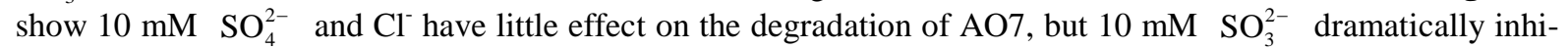
bits the degradation. And the more $\mathrm{SO}_{3}^{2-}$ in the mixture, the more dramatic inhibition effects. So the reductive

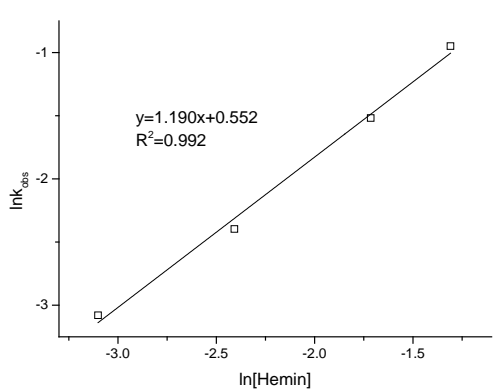

(a)

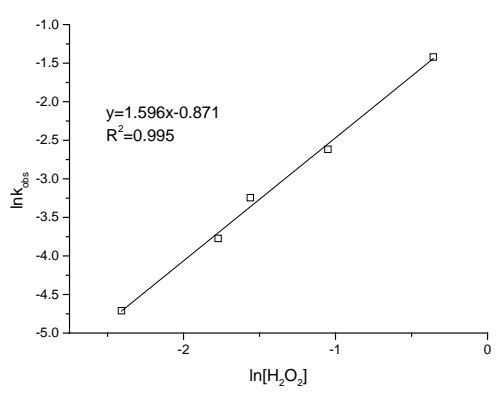

(b)

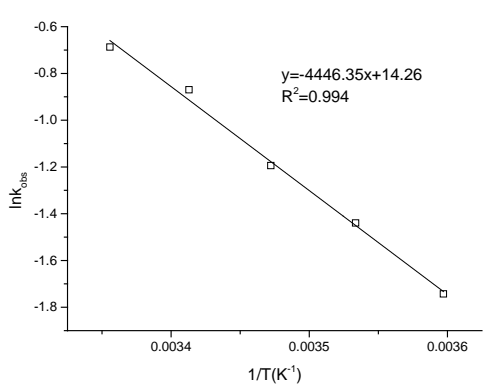

(c)

Figure 1. Plots of $\ln _{\text {kobs }}$ versus $\ln [\mathrm{Hemin}](\mathrm{a}), \ln \left[\mathrm{H}_{2} \mathrm{O}_{2}\right]$ (b) and $1 / \mathrm{T}$ (c) ([AO7] $\left.0.18 \mathrm{mM}\right) .(\mathrm{a})\left[\mathrm{H}_{2} \mathrm{O}_{2}\right] 0.70 \mathrm{mM}, \mathrm{T} 15^{\circ} \mathrm{C}$; (b) [Hemin] $0.18 \mu \mathrm{M}, \mathrm{T} 15^{\circ} \mathrm{C}$; (c) [Hemin] $0.27 \mu \mathrm{M},\left[\mathrm{H}_{2} \mathrm{O}_{2}\right] 0.35 \mathrm{mM}$. 

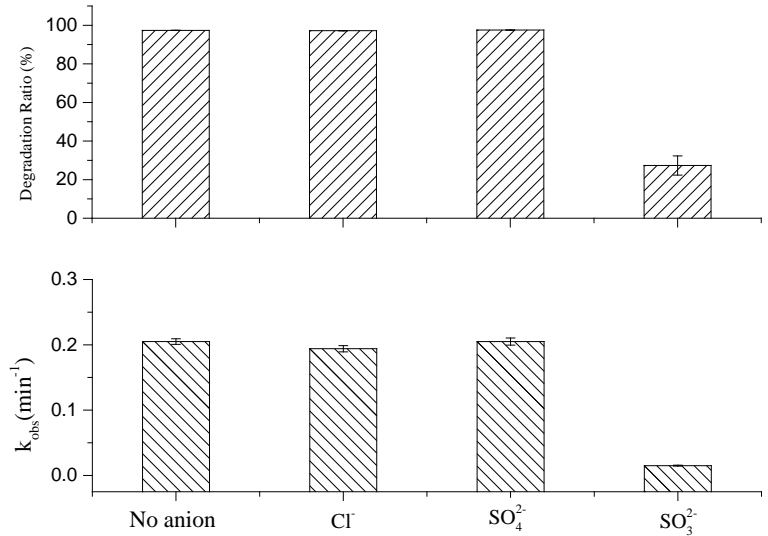

(a)

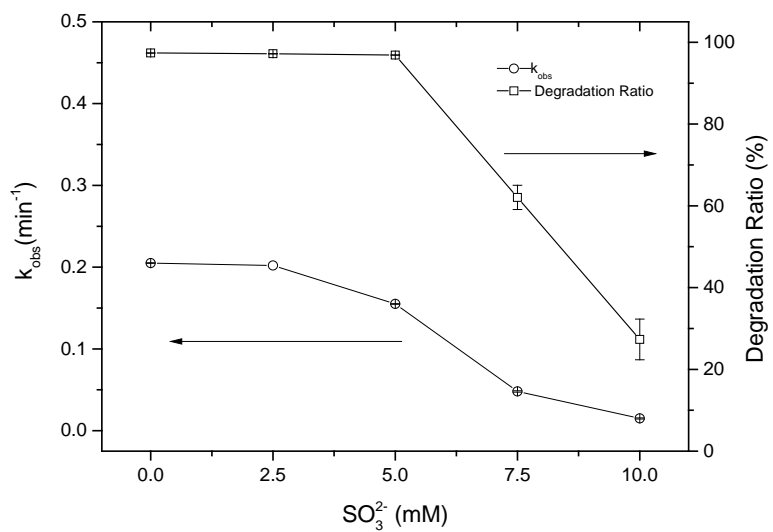

(b)

Figure 2. Effects of chloride, sulfite or sulfate ions on color removal of AO7 (a) and Effects of the sulfite concentration on the color removal of AO7 (b). Experiment conditions: [AO] $0.07 \mathrm{mM},\left[\mathrm{H}_{2} \mathrm{O}_{2}\right] 0.21 \mathrm{mM}$, [Hemin] $0.09 \mu \mathrm{M}, \mathrm{T} 15^{\circ} \mathrm{C}$.

interfering anions reduce the degradation rate and ratio of $\mathrm{AO} 7$ because of the competition consumption of oxidant.

\subsection{Characterization of Degradation Process}

UV-vis spectra during degradation processes are shown in Figure 3 and the peaks at $484 \mathrm{~nm}$ and $430 \mathrm{~nm}$ are correspond to the $\mathrm{n} \rightarrow \pi^{*}$ transition of the azo and hydrazone form, respectively. Other two bands at 250 and $310 \mathrm{~nm}$ are attributed to the $\pi \rightarrow \pi^{*}$ transition of benzene and naphthalene ring, respectively [1] [2] [29] [30]. The main band at $484 \mathrm{~nm}$ decreased quickly, but there was a new band appeared obviously at $343 \mathrm{~nm}$ and increased at first $5 \mathrm{~min}$, then decreased with time prolonged. At the same time, the absorbance at $250-255 \mathrm{~nm}$ also increased and a new should peak appeared at $252 \mathrm{~nm}$. The inset of Figure $\mathbf{3}$ is the absorbance evolution at 343 and $252 \mathrm{~nm}$. These changes indicate that some naphthalene- and/or benzene-type intermediates form during degradation process.

Figure 4 presents the FTIR spectra of samples during degradation of AO7. In spectra of 0 min, the band at $1266 \mathrm{~cm}^{-1}$ is assigned to the vibration stretching mode $v(\mathrm{C}-\mathrm{N})$ [31], and the band at $1384 \mathrm{~cm}^{-1}$ is $v(\mathrm{~N}=\mathrm{N})$ and o-quinone structure[32]. The bands near $1730 \mathrm{~cm}^{-1}$ is attributed to the $v(\mathrm{C}=\mathrm{O})$ and $1459 \mathrm{~cm}^{-1}$ is $v(\mathrm{C}=\mathrm{C})$ in aromatic ring (benzene or naphthalene ring). During oxidative process, the band at $1266 \mathrm{~cm}^{-1}$ became weaker and soon disappeared, which was in accord with the peak changes at $484 \mathrm{~nm}$ in UV-vis spectra. This indicates the break of bands C-N in the dye molecular. The new bands near $1723 \mathrm{~cm}^{-1}$ was in accord with peak changes at $343 \mathrm{~nm}$ in UV-vis spectra and could be associated to the aromatic rings change.

Figure 5 shows the dissolved oxygen(DO) evolution during AO7 degradation. It was observed the DO increased at first, then decreased with time. It suggests that the reaction of AO7 in hemin/system at selected conditions involves $\mathrm{O}_{2}$ releasing. Kalyanararna et al. [33] have reported several reactions of $\mathrm{H}_{2} \mathrm{O}_{2}$ reactions with hematin involving $\mathrm{O}_{2}$ release. But different changes were observed in Alizarin/hemetin $/ \mathrm{H}_{2} \mathrm{O}_{2}$ system by S. Pirillo et al. [5] Our results in the AO7/hemin $/ \mathrm{H}_{2} \mathrm{O}_{2}$ system indicated that the reactions of oxygen release are also the important reactions in the presence of hemin as catalyst.

In hemin $/ \mathrm{H}_{2} \mathrm{O}_{2}$ system, the $\mathrm{O}-\mathrm{O}$ bond in $\mathrm{H}_{2} \mathrm{O}_{2}$ is thought to heterolytic cleavage, giving rise to the active species oxoferryl porphyrin $\pi$-cation radical ${ }^{+} \mathrm{PFe}^{\mathrm{IV}}=\mathrm{O}$. Then the rapid reduction of $\mathrm{Fe}^{\mathrm{IV}}$ by $\mathrm{H}_{2} \mathrm{O}_{2}$ happens [33][36]:

$$
\begin{aligned}
& \mathrm{PFe}^{\mathrm{III}}+\mathrm{H}_{2} \mathrm{O}_{2} \rightarrow{ }^{+} \mathrm{PFe}^{\mathrm{IV}}=\mathrm{O} \\
& { }^{+} \mathrm{PFe}^{\mathrm{IV}}=\mathrm{O}+\mathrm{H}_{2} \mathrm{O}_{2} \rightarrow\left[\mathrm{PFe}^{\mathrm{III}-} \mathrm{O}_{2}^{-}\right] \rightarrow \mathrm{PFe}^{\mathrm{II}}+\mathrm{O}_{2}
\end{aligned}
$$

Then $\mathrm{O}_{2}$ may be consumed by the species formed at prior stage or the dye itself. $\mathrm{H}_{2} \mathrm{O}_{2}$ decomposed easily at basic medium, so the DO is higher in the blank system in which no hemin was added, but the degradation of 


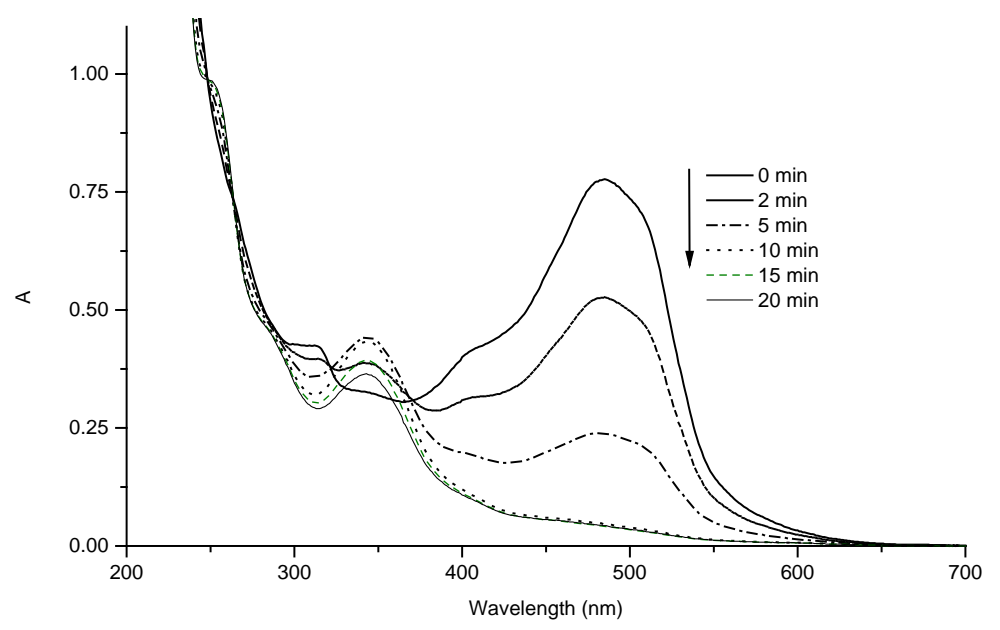

Figure 3. Uv-vis spectra changes during the degradation of AO7. [AO] 0.07 $\mathrm{mM},\left[\mathrm{H}_{2} \mathrm{O}_{2}\right] 0.09 \mathrm{mM}$, [Hemin] $0.09 \mu \mathrm{M}, \mathrm{T} 15^{\circ} \mathrm{C}$.

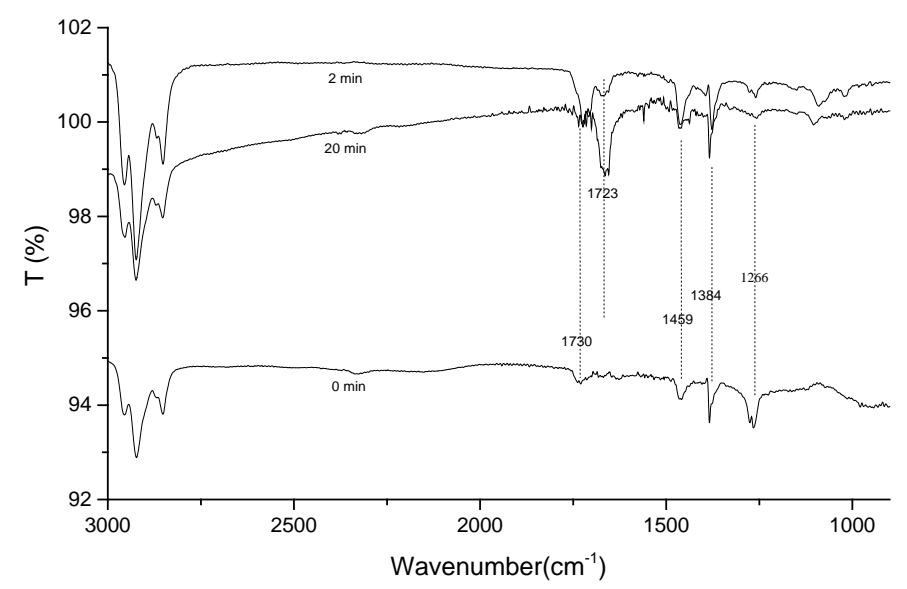

Figure 4. FTIR spectra changes during the degradation of AO7.

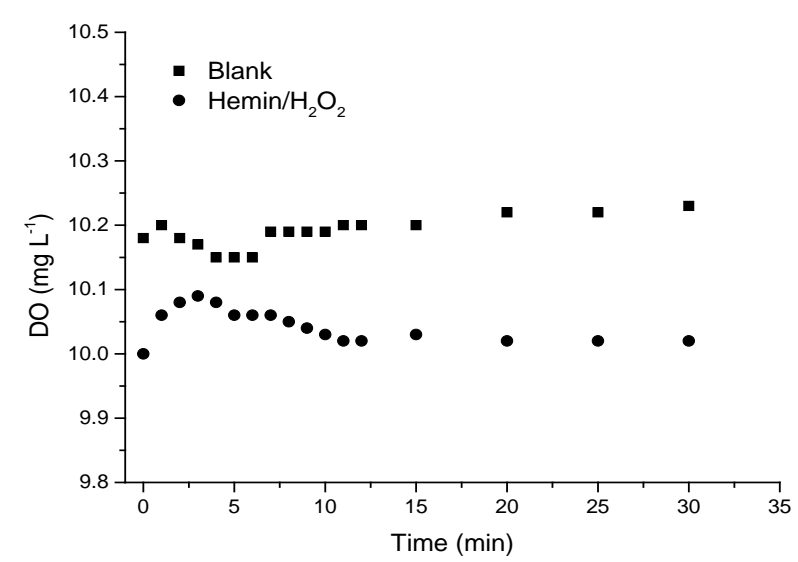

Figure 5. Dissolved oxygen evolution for AO7 degradation process and for Blank at pH 11.0. [AO7] $0.18 \mathrm{mM}$; [ $\mathrm{H}_{2} \mathrm{O}_{2}$ ] $0.35 \mathrm{mM}$; [hemin] $0.27 \mu \mathrm{M}$; $\mathrm{T} 15^{\circ} \mathrm{C}$.

AO7 does not achieve. The results indicate that the oxidative of $\mathrm{AO}$ by $\mathrm{O}_{2}$ directly should not be the main reaction.

The main reaction of consuming $\mathrm{O}_{2}$ is the formation of the superoxide anion [35]: 


$$
\mathrm{PFe}^{\mathrm{II}}+\mathrm{O}_{2} \rightarrow \mathrm{PFe}^{\mathrm{III}}+\mathrm{O}_{2}^{--}
$$

It has been proposed that the reaction in hematin $/ \mathrm{H}_{2} \mathrm{O}_{2}$ system is analogous to the classical Fenton reaction and hematin mainly generates $\cdot \mathrm{OH}$ radicals in some literatures [5] [19] [33]. In order to check if $\cdot \mathrm{OH}$ radicals are involved in $\mathrm{AO} 7$ degradation in hemin $/ \mathrm{H}_{2} \mathrm{O}_{2}$ system, the effects of adding 2-propanol, an $\cdot \mathrm{OH}$ radical scavenger [1], on the dye degradation is compared in Figure 6.

It is interesting that the degradation rate and and ratio of $\mathrm{AO} 7$ is promoted by adding excess 2-propanol under low $\mathrm{H}_{2} \mathrm{O}_{2}$ concentration. The results indicate that $\cdot \mathrm{OH}$ radicals are not the main roles of degradation of $\mathrm{AO} 7$ in hemin $/ \mathrm{H}_{2} \mathrm{O}_{2}$ system in alkaline medium.

$\mathrm{SO}_{4}^{2-}$ showed $\cdot \mathrm{OH}$ scavenging effect when dye was oxidized by photo-catalyzing and inhibited the degradation of dye, but $\mathrm{SO}_{3}^{2-}$ has little this effect [37]. But in our studies, $10 \mathrm{mM} \mathrm{SO}_{4}^{2-}$ had little effect on the degradation of $\mathrm{AO} 7$ and $10 \mathrm{mM} \mathrm{SO}{ }_{3}^{2-}$ greatly inhibited the degradation of AO7. The different effects of $\mathrm{SO}_{4}^{2-}$ and $\mathrm{SO}_{3}^{2-}$ in $\mathrm{TiO}_{2} / \mathrm{UV}$ and hemin/ $\mathrm{H}_{2} \mathrm{O}_{2}$ systems also illustrate that the $\cdot \mathrm{OH}$ radicals are not main roles of degradation of $\mathrm{AO} 7$ in hemin $/ \mathrm{H}_{2} \mathrm{O}_{2}$ system.

It has been proposed that protic solvents, including 2-propanol, facilitates $\mathrm{O}-\mathrm{O}$ bond heterolysis, resulting the high-valence oxoiron(IV) porphyrin $\pi$-cation radicals and with the increase of the amounts of alcohol solvents in reaction solutions, the iron porphyrin complex became more electron-deficient[38]. On the other hand, the protic solvents can form $\mathrm{H}$-bond with the $-\mathrm{OH}$ in the azo dye, which was benefit for stabilization of azo form [22]. Taking electronic nature of hemin and AO7 structure affected by 2-propanol into considerations, it is assumed that the ${ }^{\cdot+} \mathrm{PFe}^{\mathrm{IV}}=\mathrm{O}$ play the important role for degradation of $\mathrm{AO} 7$ in hemin $/ \mathrm{H}_{2} \mathrm{O}_{2}$ system.

\subsection{Reaction Pathways}

To further identify the intermediate products, GC-MS analysis is employed and the intermediate products are identified by comparing the GC spectra and $\mathrm{m} / \mathrm{z}$ fragments at different reaction time. Taking all the characterizations of degradation analyzed above into consideration, Figure 7 shows the proposed degradation pathway of AO7 in hemin $/ \mathrm{H}_{2} \mathrm{O}_{2}$ system. The O-O bond in $\mathrm{H}_{2} \mathrm{O}_{2}$ cleave heterolyticly and the active species ${ }^{+} \mathrm{PFe}^{\mathrm{IV}}=\mathrm{O}$ is produced. The cooperative effects of the $\pi-\pi$ and electrostatic interactions between the ${ }^{\cdot+} \mathrm{PFe}^{\mathrm{IV}}=\mathrm{O}$ and azo form of AO7 [2] [34] [39] is favor for the electro transfer from the azo chromophoric to the active species of
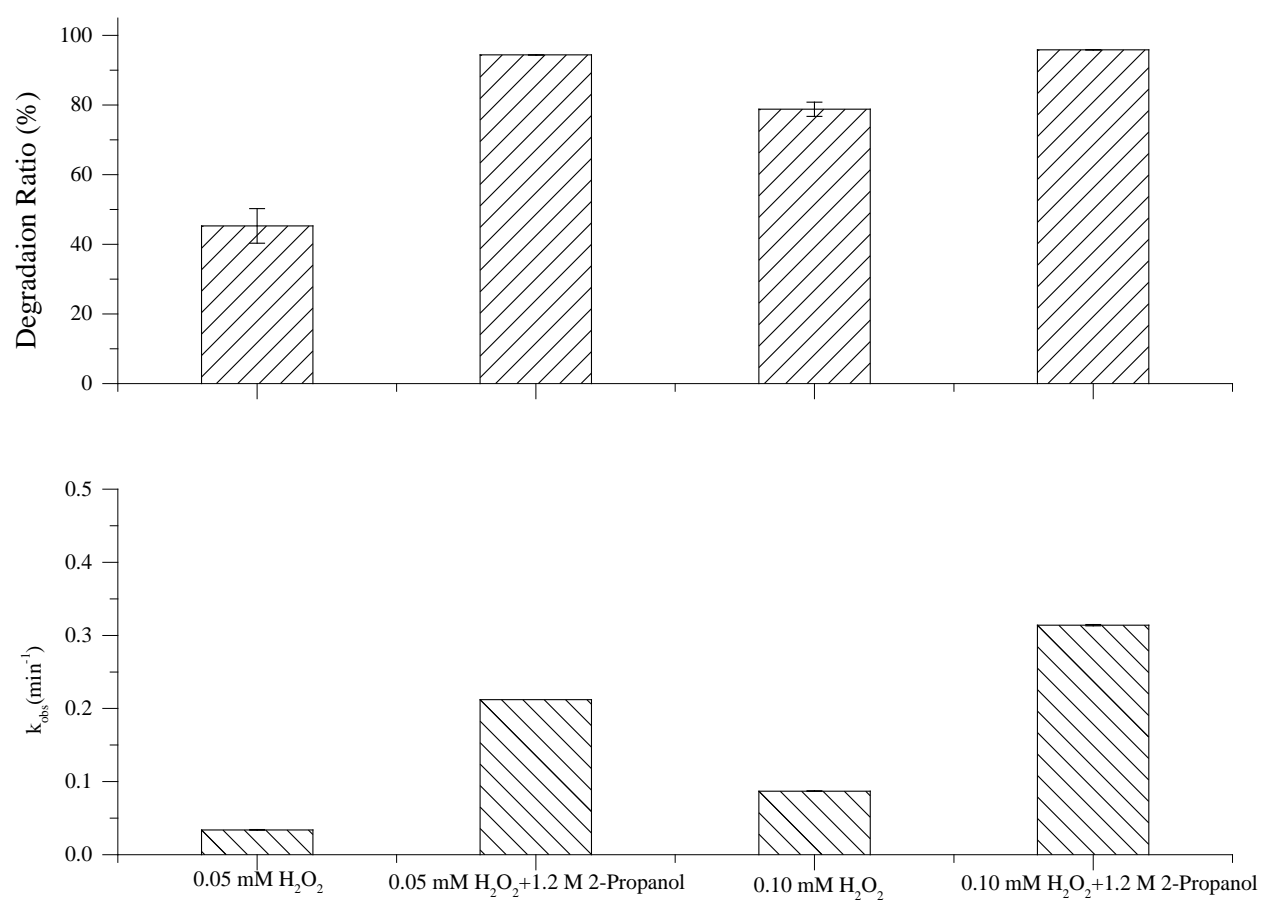

Figure 6. Effects of 2-propanol on degradation of AO7. [AO] $0.07 \mathrm{mM}$, [Hemin] $0.09 \mu \mathrm{M}, \mathrm{T} 15^{\circ} \mathrm{C}$. 


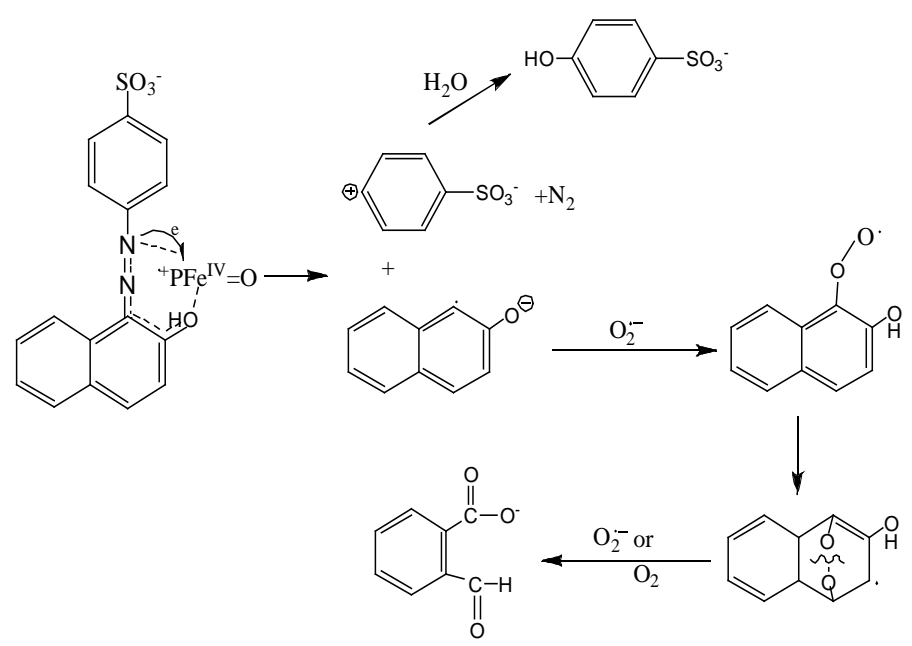

Figure 7. Proposed reaction pathway of AO7 degradation in hemin $/ \mathrm{H}_{2} \mathrm{O}_{2}$ system.

${ }^{+} \mathrm{PFe}^{\mathrm{IV}}=\mathrm{O}$. Azo chromogenic group is destroyed and benzenesulfonated cation and 2-naphothol radical species form, then they react subsequently with water or superoxide anion to form the products.

\section{Conclusions}

Oxidative degradation of AO7 with low concentration hydrogen peroxide under hemin catalysis can be achieved in alkaline aqueous solution. Degradation process can be described by a pseudo-first-order kinetic model. The order of dependence on $\mathrm{H}_{2} \mathrm{O}_{2}$ concentration is significantly larger than that of hemin. Coexisting anions sulphate and chloride have little effect on the degradation, but the reductive sulphite dramatically inhibits the degradation. The protic solvent 2-prophanol obviously promotes the degradation. The azo chromogenic group can be destroyed quickly in hemin $/ \mathrm{H}_{2} \mathrm{O}_{2}$ system and some smaller intermediates forms during the first degradation of AO7. The active species oxoferryl porphyrin $\pi$-cation radical ${ }^{+} \mathrm{PFe}^{\mathrm{IV}}=\mathrm{O}$ generated from heterolytic cleavage of $\mathrm{O}-\mathrm{O}$ in $\mathrm{H}_{2} \mathrm{O}_{2}$ catalyzed by hemin plays main roles in degradation of AO7.

\section{Acknowledgements}

This work was supported by the National Natural Science Foundation of China (No. 1120589 and No. 21575066).

\section{References}

[1] Park, H. and Choi, W. (2003) Visible Light and Fe(III)-Mediated Degradation of Acid Orange 7 in the Absence of $\mathrm{H}_{2} \mathrm{O}_{2}$. Journal of Photochemistry and Photobiology A: Chemistry, 159, 241-247. http://dx.doi.org/10.1016/S1010-6030(03)00141-2

[2] Barros, V.P. and Assis, M.D. (2013) Iron Porphyrins as Biomimetical Models for Disperse Azo Dye Oxidation. Journal of the Brazilian Chemical Society, 24, 830-836. http://dx.doi.org/10.5935/0103-5053.20130110

[3] Córdoba, A., Magario, I. and Ferreira, M.L. (2012) Evaluation of Hematin-Catalyzed Orange II Degradation as a Potential Alternative to Horseradish Peroxidase. International Biodeterioration \& Biodegradation, 3, 60-72. http://dx.doi.org/10.1016/j.ibiod.2012.05.020

[4] Ozcan, A., Oturan, M.A., Oturan, N. and Sahin, Y. (2009) Removal of Acid Orange 7 from Water by Electrochemically Generated Fenton’s Reagent. Journal of Hazardous Materials, 163, 1213-1220. http://dx.doi.org/10.1016/j.jhazmat.2008.07.088

[5] Pirillo, S., Einschlag, F.S.G., Rueda, E.H. and Ferreira, M.L. (2010) Horseradish Peroxidase and Hematin as Biocatalysts for Alizarin Degradation Using Hydrogen Peroxide. Industrial \& Engineering Chemistry Research, 49, 67456752. http://dx.doi.org/10.1021/ie901528y

[6] Shah, M. (2014) Effective Treatment Systems for Azo Dye Degradation: A Joint Venture between Physico-Chemical \& Microbiological Process. Int. J. Environ. Biorem. Biodegrad., 2, 231-242. 
[7] Saratale, R.G., Saratale, G.D., Chang, J.S. and Govindwar, S.P. (2011) Bacterial Decolorization and Degradation of Azo Dyes: A Review. Journal of the Taiwan Institute of Chemical Engineers, 42, 138-157. http://dx.doi.org/10.1016/j.jtice.2010.06.006

[8] Gottlieb, A., Shaw, C., Smith, A., Wheatley, A. and Forsythe, S. (2003) The Toxicity of Textile Reactive Azo Dyes after Hydrolysis and Decolourisation. Journal of Biotechnology, 101, 49-56. http://dx.doi.org/10.1016/S0168-1656(02)00302-4

[9] Mantzavinos, D. and Psillakis, E. (2004) Enhancement of Biodegradability of Industrial Wastewaters by Chemical Oxidation Pre-Treatment. Journal of Chemical Technology and Biotechnology, 79, 431-454. http://dx.doi.org/10.1002/jctb.1020

[10] Serra, A.C., Docal, C. and Rocha Gonsalves, A.M.d’A. (2005) Efficient Azo Dye Degradation by Hydrogen Peroxide Oxidation with Metalloporphyrins as Catalysts. Journal of Molecular Catalysis A: Chemical, 238, 192-198. http://dx.doi.org/10.1016/j.molcata.2005.05.017

[11] Zubir, N.A., Yacou, C., Zhang, X. and Diniz da Costa, J.C. (2014) Optimisation of Graphene Oxide-Iron Oxide Nanocomposite in Heterogeneous Fenton-Like Oxidation of Acid Orange 7. Journal of Environmental Chemical Engineering, 2, 1881-1888. http://dx.doi.org/10.1016/j.jece.2014.08.001

[12] Yao, Y., Mao, Y., Huang, Q., Wang, L., Huang, Z., Lu, W. and Chen, W. (2014) Enhanced Decomposition of Dyes by Hemin-ACF with Significant Improvement in pH Tolerance and Stability. Journal of Hazardous Materials, 264, 323331. http://dx.doi.org/10.1016/j.jhazmat.2013.10.063

[13] Xie, W. and Ruan, X. (2013) Characteristics of Printing and Dyeing Wastewater Quality from Industrial Park in the South Part of Jiangsu. Guangzhou Chemical Industry, 41, 152-154.

[14] Mohan, S.V., Prasad, K.K., Rao, N.C. and Sarma, P.N. (2005) Acid Azo Dye Degradation by Free and Immobilized Horseradish Peroxidase (HRP) Catalyzed Process. Chemosphere, 58, 1097-1105. http://dx.doi.org/10.1016/j.chemosphere.2004.09.070

[15] Zhang, A.P., Fang, L., Wang, J.L. and Liu, W.P. (2013) Enzymatic Decolorization of Orange II: Optimization by Response Surface Methodology and Pathway. Environmental Progress \& Sustainable Energy, 32, 294-301. http://dx.doi.org/10.1002/ep.11628

[16] Mielgo, I., Lopez, C., Moreira, M.T., Feijoo, G. and Lema, J.M. (2003) Oxidative Degradation of Azo Dyes by Manganese Peroxidase under Optimized Conditions. Biotechnol. Progr., 19, 325-331. http://dx.doi.org/10.1021/bp020136w

[17] Ollikka, P., Harjunpää, T., Palmu, K., Mäntsälä, P. and Suominen, I. (1998) Oxidation of Crocein Orange G by Lignin Peroxidase Isoenzymes Kinetics and Effect of $\mathrm{H}_{2} \mathrm{O}_{2}$. Applied Biochemistry and Biotechnology, 75, 307-321. http://dx.doi.org/10.1007/BF02787783

[18] Coelho, P.S., Brustad, E.M., Kannan, A. and Arnold, F.H. (2013) Olefin Cyclopropanation via Carbene Transfer Catalyzed by Engineered Cytochrome P450 Enzymes. Science, 339, 307-310. http://dx.doi.org/10.1126/science.1231434

[19] Pirillo, S., Einschlag, F.S.G., Ferreira, M.L. and Rueda, E.H. (2010) Eriochrome Blue Black R and Fluorescein Degradation by Hydrogen Peroxide Oxidation with Horseradish Peroxidase and Hematin as Biocatalysts. Journal of Molecular Catalysis B: Enzymatic, 66, 63-71. http://dx.doi.org/10.1016/j.molcatb.2010.03.003

[20] de Villiers, K.A., Kaschula, C.H., Egan, T.J. and Marques, H.M. (2007) Speciation and Structure of Ferriprotoporphyrin IX in Aqueous Solution: Spectroscopic and Diffusion Measurements Demonstrate Dimerization, but Not Mu-Oxo Dimer Formation. JBIC Journal of Biological Inorganic Chemistry, 12, 101-117. http://dx.doi.org/10.1007/s00775-006-0170-1

[21] Perez-Urquiza, M. and Beltran, J.L. (2001) Determination of the Dissociation Constants of Sulfonated Azo Dyes by Capillary Zone Electrophoresis and Spectrophotometry Methods. Journal of Chromatography A, 917, 331-336. http://dx.doi.org/10.1016/S0021-9673(01)00707-5

[22] Wu, Z., Zhang, R. and Rong, Z. (2014) The Azo-Hydrazone Tautomerism of Azo Dyes. Dyestuffs and Coloration, 51, $1-11,22$.

[23] Kuramitz, H., Nakata, Y., Kawasaki, M. and Tanaka, S. (2001) Electrochemical Oxidation of Bisphenol A. Application to the Removal of Bisphenol A Using a Carbon Fiber Electrode. Chemosphere, 45, 37-43. http://dx.doi.org/10.1016/S0045-6535(01)00032-7

[24] Li, G., Qu, J., Zhang, X., Liu, H. and Liu, H. (2006) Electrochemically Assisted Photocatalytic Degradation of Orange II: Influence of Initial pH Values. Journal of Molecular Catalysis A: Chemical, 259, 238-244. http://dx.doi.org/10.1016/j.molcata.2006.06.038

[25] Simončič, B., Špan, J. and Vesnaver, G. (1994) A Study of the Self-Association of Simple Azo Dyes Using the Potentiometric Method. Dyes and Pigments, 26, 257-276. http://dx.doi.org/10.1016/0143-7208(94)80041-3

[26] Kong, J., Yu, X., Hu, W., Hu, Q., Shui, S., Li, L., Han, X., Xie, H., Zhang, X. and Wang, T. (2015) A Biomimetic En- 
zyme Modified Electrode for $\mathrm{H}_{2} \mathrm{O}_{2}$ Highly Sensitive Detection. Analyst, 140, 7792-7798. http://dx.doi.org/10.1039/C5AN01335F

[27] Yuranova, T., Enea, O., Mielczarski, E., Mielczarski, J., Albers, P. and Kiwi, J. (2004) Fenton Immobilized PhotoAssisted Catalysis through a Fe/C Structured Fabric. Applied Catalysis B: Environmental, 49, 39-50. http://dx.doi.org/10.1016/j.apcatb.2003.11.008

[28] Arslan-Alaton, I. (2003) A Review of the Effects of Dye-Assisting Chemicals on Advanced Oxidation of Reactive Dyes in Wastewater. Coloration Technology, 119, 345-353. http://dx.doi.org/10.1111/j.1478-4408.2003.tb00196.x

[29] Zhang, S.-J., Yu, H.-Q. and Li, Q.-R. (2005) Radiolytic Degradation of Acid Orange 7: A Mechanistic Study. Chemosphere, 61, 1003-1011. http://dx.doi.org/10.1016/j.chemosphere.2005.03.008

[30] Wu, F., Deng, N.S. and Hua, H.L. (2000) Degradation Mechanism of Azo Dye C.I. Reactive Red 2 by Iron Powder Reduction and Photooxidation in Aqueous Solutions. Chemosphere, 41, 1233-1238. http://dx.doi.org/10.1016/S0045-6535(99)00538-X

[31] Bauer, C., Jacques, P. and Kalt, A. (1999) Investigation of the Interaction between a Sulfonated Azo Dye (AO7) and a $\mathrm{TiO}_{2}$ Surface. Chemical Physics Letters, 307, 397-406. http://dx.doi.org/10.1016/S0009-2614(99)00518-7

[32] Saito, Y., Kim, B.-K., Machida, K. and Uno, T. (1974) Resonace Raman Spectra of Acid-Base Indicators. II. Hydroxyarylazobenzene Derivatives. Bull. Chem. Soc. Jpn., 47, 2111-2114. http://dx.doi.org/10.1246/bcsj.47.2111

[33] Kalyanaraman, B., Mottley, C. and Mason, R.P. (1983) A Direct Electron Spin Resonance and Spin-Trapping Investigation of Peroxyl Free Radical Formation by Hematin/Hydroperoxide Systems. J. Biol. Chem., 258, 3855-3858.

[34] Nam, W., Han, H. J., Oh, S.Y., Lee, Y.J., Choi, M.H., Han, S.Y., Kim, C., Woo, S.K. and Shin, W. (2000) New Insights into the Mechanisms of O-O Bond Cleavage of Hydrogen Peroxide and Tert-Alkyl Hydroperoxides by Iron(III) Porphyrin Complexes. J. Am. Chem. Soc., 122, 8677-8684. http://dx.doi.org/10.1021/ja994403e

[35] Vlasits, J., Jakopitsch, C., Bernroitner, M., Zamocky, M., Furtmüller, P.G. and Obinger, C. (2010) Mechanisms of Catalase Activity of Heme Peroxidases. Archives of Biochemistry and Biophysics, 500, 74-81. http://dx.doi.org/10.1016/j.abb.2010.04.018

[36] Bruice, T. C. (1991) Reactions of Hydroperoxides with Metallotetraphenylporphyrins in Aqueous Solutions. Acc. Chem. Res., 24, 243-249. http://dx.doi.org/10.1021/ar00008a004

[37] Sokmen, M. and Ozkan, A. (2002) Decolourising Textile Wastewater with Modified Titania: The Effects of Inorganic anions on the Photocatalysis. J. Photoch. Photobio. A, 147, 77-81. http://dx.doi.org/10.1016/S1010-6030(01)00627-X

[38] Nam, W., Oh, S.Y., Sun, Y.J., Kim, J., Kim, W.K., Woo, S.K. and Shin, W. (2003) Factors Affecting the Catalytic epoxidation of Olefins by Iron Porphyrin Complexes and $\mathrm{H}_{2} \mathrm{O}_{2}$ in Protic Solvents. The Journal of Organic Chemistry, 68, 7903-7906. http://dx.doi.org/10.1021/jo034493c

[39] Mac Leod, T.C.O., Faria, A.L., Barros, V.P., Queiroz, M.E.C. and Assis, M.D. (2008) Primidone Oxidation Catalyzed by Metalloporphyrins and Jacobsen Catalyst. Journal of Molecular Catalysis A: Chemical, 296, 54-60. http://dx.doi.org/10.1016/j.molcata.2008.09.008 